\title{
STRATEGI PENGEMBANGAN LADA (STUDI KASUS KELOMPOK TANI INDATU DI DESA BLANG PANYANG KECAMATAN MUARA SATU KOTA LHOKSEUMAWE)
}

\author{
(Strategy of pepper development (case study of indatu farmer group in blang panyang village \\ sub-district estuary one, Lhokseumawe City)
}

\author{
Auzan Syahmi ${ }^{1}$, Romano $^{1}$, Irwan A, Kadir $^{1 *}$ \\ ${ }^{1}$ Program Studi Agribisnis, Fakultas Pertanian, Universitas Syiah Kuala
}

\begin{abstract}
Abstrak . Lada merupakan salah satu tanaman rempah-rempah yang berasal dari tanaman perkebunan yang sangat terkenal dahulu di Aceh. Khususnya Petani lada di Aceh saat ini sudah mulai memperhatikan lada untuk dikembangkan dengan tujuan meningkatkan pendapatan dan kesejahteraan. Dengan kata lain, Lada menjadi komoditi primadona yang banyak diminati di perdagangan dunia. Karena berbagai negara menggunakan lada ini sebagai bumbu dapur masakan. Disisi lain disebabkan berkembangnya usaha makanan, berkembangnya industri farmasi, kosmetika yang menggunakan lada sebagai salah satu bahan baku, meningkatnya konsumsi dunia, konsumsi dalam negeri semakin meningkat dengan bertambahnya produk-produk industri makanan berbasis lada. Akibat permintaan lada yang tinggi menyebabkan terjadinya masalah bagi petani Aceh dalam keterbatasan produksi lada. Salah satunya lahan pertanian dikonversikan menjadi non pertanian seperti perumahan, gedung dan pertokoan. Sehingga lahan pertanian menjadi berkurang dan menjadi masalah bagi petani lada sendiri dalam mengembangkan lada. Penyebab masalah lain juga yang akibat hama dan penyakit terutama penyakit layu, penyakit keriting daun serta penyakit busuk pangkal batang. Tujuan Penelitian untuk mengetahui faktor-faktor yang diperhatikan pada pengembangan lada, serta mengetahui strategi pengembangan lada yang tepat. Metode Penelitian yang digunakan adalah metode studi kasus. Teknik Pengumpulan data digunakan dengan pendekatan wawancara. Hasil analisis menunjukkan faktor internal yang mempengaruhi usaha pengembangan lada adalah bibit, pestisida, sumber daya alam, pupuk, dan sumber daya manusia. Sedangkan faktor eksternal yang mempengaruhinya adalah pemerintah, pasar, harga, pesaing, hama dan penyakit. Berdasarkan hasil analisis SWOT didapatkan nilai IFAS (Internal Strategic Factors Analysis Summary) sebesar 1,756 dan EFAS (Eksternal Strategic Factors Analysis Summary) sebesar 2,773 berada pada kuadran I , maka strategi pengembangan yang cocok untuk strategi pengembangan lada adalah strategi agresif yang artinya usaha tersebut sangat dimungkinkan untuk terus berkembang, meningkatkan pertumbuhan dan meraih kemajuan secara maksimal, dimana strategi agresif ini merupakan kondisi yang sangat menguntungkan, peluang dan kekuatan begitu besar sehingga pelaku usaha bisa memanfaatkan peluang dan kekuatan yang ada secara maksimal.
\end{abstract}

Kata Kunci : Strategi Pengembangan Lada, Kelompok Tani Indatu, Analisis SWOT.

Abstract. Pepper is one of the most popular herbs from Aceh plantations. Especially pepper farmers in Aceh are now starting to pay attention to pepper to be developed with the aim of increasing income and welfare. In other words, Pepper became the most popular commodity in the world trade. Because various countries use this pepper as a spice cooking kitchen. On the other hand, due to the development of food business, the development of pharmaceutical industry, cosmetics using pepper as one of the raw materials, the increasing of world consumption, domestic consumption is increasing with the increase of pepper based food industry products. As a result of high pepper demand causes problems for Acehnese farmers in the limitations of pepper production. One of them agricultural land converted into non-agricultural such as housing, buildings and shops. So that agricultural land becomes reduced and become a problem for pepper farmers themselves in developing pepper. Other causes of problems are also caused by pests and diseases, especially wilt disease, leaf curling disease and stem rot disease. Research Objectives to determine the factors that are considered in the development of pepper, as well as to know the appropriate pepper development strategy. The research method used is case study method. Technique Data collection is used with interview approach. The results of the analysis show that the internal factors affecting pepper development are seeds, pesticide, natural resources, fertilizer and human resources. While on external factors that include government, markets,prices, competitors,pest and diseases. Based on the result of SWOT analysis, the value of

*Corresponding author: Irwankadir58@gmail.com 
IFAS (Internal Strategic Factors Analysis Summary) of 1.756 and EFAS (External Strategic Factors Analysis Summary) of 2.773 are in quadrant I, then a suitable development strategy for pepper development strategy is aggressive strategy which means the business is very possible To continue to grow, to increase growth and to achieve maximum progress, where aggressive strategy is a very favorable condition, opportunities and strength so large that business actors can take advantage of opportunities and strengths that exist maximally.

Keywords : Strategy of Pepper Development, indatu farmer group, SWOT analysis

\section{PENDAHULUAN}

Lada (Piper nigrum Linn.) merupakan tanaman rempah- rempah yang sudah lama dikembangkan di Indonesia. Tanaman lada ini berasal dari daerah Ghat Barat, India. Tingginya permintaan tanaman perkebunan ini menjadikan lada sebagai The king of spice (Raja rempah-rempah). Tanaman rempah ini umumnya sangat sering digunakan untuk bumbu dapur penyedap masakan, karena memiliki rasa dan aroma yang khas sehingga dapat meningkatkan cita rasa pada makanan (Wahid, 1996).

Selain sebagai bumbu masakan, tanaman yang sering disebut merica ini memiliki khasiat bagi kesehatan. Di antaranya dapat menurunkan berat badan, meringankan radang sendi, membunuh sel kanker prostat, mengurangi gejala nyeri sakit kepala, membantu melonggarkan pernafasan saat hidung tersumbat dan dapat menghangatkan badan. Secara ekonomis, lada ini memiliki peran penting dalam meningkatkan pendapatan dan kesejahteraan petani (Direktorat Jenderal Bina Produksi Perkebunan, 2002).

Khususnya Petani lada di Aceh yang saat ini mulai memperhatikan lada untuk dikembangkan dengan tujuan meningkatkan pendapatan dan kesejahteraan. Bahkan Lada menjadi komoditi primadona yang banyak diminati di perdagangan dunia. Karena berbagai negara menggunakan lada ini sebagai bumbu dapur masakan. Permintaan lada yang tinggi ini disebabkan karena berkembangnya usaha makanan, berkembangnya industri farmasi, kosmetika yang menggunakan lada sebagai salah satu bahan baku, meningkatnya konsumsi dunia, konsumsi dalam negeri semakin meningkat dengan bertambahnya produk-produk industri makanan berbasis lada. Akibat permintaan lada yang tinggi menyebabkan terjadinya masalah bagi petani Aceh dalam keterbatasan produksi lada.

Menurut Kemala 2006, dalam penelitiannya yang berjudul "Strategi Pengembangan Sistem Agribisnis Lada untuk meningkatkan pendapatan petani di Perkebunan Kota Bogor". Hasil penelitian ini menyatakan bahwa strategi pengembangan yang dapat diterapkan dalam pengembangan agribisnis tanaman lada di antara lain adalah strategi pada sub sistem hulu, strategi pada subsistem produksi, strategi pada sub sistem pengolahan hasil, strategi pada sub sistem pemasaran lada, strategi pada sub sistem kelembagaan dan penunjang. Diharapkan jika sub sistem tersebut bisa dijalankan dengan sebaik mungkin maka akan meningkatkan produktivitas dan mensejahterakan taraf hidup para petani.

Menurut Nurmagribah 2006, dalam penelitiannya yang berjudul "Strategi Pengembangan Usaha (Studi Kasus pada Diana Bakery Kota Bekasi Jawa Barat) ada beberapa faktor kekuatan yang mendapat skor tertinggi adalah kualitas produk baik, hubungan yang baik antara pimpinan dan karyawan dan aktivitas penjualan yang optimal. Sedangkan pada faktor kelemahan yang menjadi skor terendah adalah kurangnya pelatihan bagi pimpinan dan karyawan, kemudian disusul kapasitas produksi yang belum optimal dan distribusi

Strategi Pengembangan Lada (Studi kasus Kelompok Tani Indatu di Desa Blang Panyang Kecamatan 
pemasaran kurang luas. Berdasarkan uraian tersebut menggambarkan bahwa prioritas strategi Diana Bakery adalah Penetrasi pasar, mempertahankan dan meningkatkan pelayanan untuk menjaga loyalitas pelanggan, memanfaatkan bantuan dari pemerintah, meningkatkan kegiatan promosi secara optimal, meningkatkan kapasitas produksi, mengadakan dan mengikuti pelatihan bagi pimpinan dan karyawan, mempertahankan dan meningkatkan kualitas produk, meningkatkan kemampuan manajemen perusahaan untuk menambah daya saing, dan memperbaiki kemasan.

Menurut Aliyah 2015 dalam penelitiannya yang berjudul "Strategi Pengembangan Usaha Pengolahan Abon Ikan (Studi Kasus Rumah Abon di Kota Bandung). Hasil penelitian menunjukkan bahwa Rumah Abon untuk kondisi saat ini cocok menerapkan strategi Agresif. Alternatif strategi yang dapat digunakan yaitu meningkatkan pengusaan teknologi pengolahan abon untuk meningkatkan produksi dan kualitas produk, meningkatkan kualitas tenaga kerja, menambah kapasitas produksi, meningkatkan modal untuk menambah kapasitas produksi dan meningkatkan kegiatan promosi. Adapun tujuan dari penelitian ini adalah untuk mengetahui faktor- faktor yang diperhatikan pada pengembangan lada serta untuk mengetahui strategi pengembangan lada yang tepat di Desa Blang Panyang Kecamatan Muara Satu Kota Lhokseumawe.

\section{METODE PENELITIAN}

Penelitian ini dilakukan di Desa Blang Panyang Kecamatan Muara Satu Kota Lhokseumawe. Lokasi penelitian ini dilakukan secara sengaja (Purposive sampling) dengan pertimbangan bahwa pengembangan lada di Desa Blang Panyang tersebut merupakan salah satu daerah produksi lada di Kota Lhokseumawe. Pada awalnya petani dan masyarakat di Desa tersebut sudah mulai mengembangkan lada sejak tahun 1997. Objek penelitian ini adalah lada yang dikembangkan oleh Kelompok Tani Indatu. Ruang lingkup penelitian ini terbatas pada strategi pengembangan lada.

\section{Metode Pengumpulan Data}

Metode penelitian yang digunakan adalah metode studi kasus (Case Study). Metode ini memusatkan perhatian dan memberikan gambaran pada suatu kasus secara mendetail yang terdapat dalam suatu objek (Nazir, 2005). Jenis data yang dikumpulkan dalam penelitian ini terdiri dari data primer dan data sekunder. Data primer yaitu data yang diambil dari pengamatan langsung di lapangan dan wawancara terhadap Ketua Kelompok Tani Indatu, Ketua Asosiasi Lada dan Forum Komunitas Hijau (FKH) dengan bantuan pertanyaan yang telah dipersiapkan terlebih dahulu. Sedangkan data sekunder yaitu data yang diperoleh dari perpustakaan, instansi yang terkait dengan penelitian ini baik instansi pemerintah maupun swasta dan sumber dari jurnal, dan literatur lainnya.

\section{Metode Analisis}

Metode analisis yang digunakan dalam penelitian adalah metode analisis SWOT secara kualitatif dan kuantitatif yaitu dengan cara menggambarkan dan menganalisis data-data yang diperoleh dilapangan secara sistematis, aktual mengenai alternatif strategi pengembangan lada ( Rangkuti, 2003). 


\section{HASIL DAN PEMBAHASAN}

\section{A. Faktor Internal Usaha Pengembangan Lada}

Faktor internal pada usaha pengembangan lada yang menjadi variabel dalam analisis SWOT terdiri dari kekuatan (S) dan Kelemahan (W) dapat dilihat pada tabel 1 berikut ini

Tabel 1 . Matrik Strategi Internal (Internal Strategic Factors Analysis Summary)

\begin{tabular}{|c|c|c|c|c|}
\hline \multirow{2}{*}{ No } & Faktor Internal & \multirow{2}{*}{ Bobot } & \multirow{2}{*}{$\begin{array}{c}\text { Rating } \\
\text { Rata- rata }\end{array}$} & \multirow{2}{*}{ Skor } \\
\hline & Kekuatan $(S)$ & & & \\
\hline 1 & Bibit yang sudah disertifikasi & 0,145 & 4,5 & 0,652 \\
\hline 2 & Memiliki lahan yang sesuai & 0,129 & 4 & 0,516 \\
\hline 3 & Loyalitas petani yang tinggi & 0,113 & 3,5 & 0,396 \\
\hline 4 & $\begin{array}{l}\text { Tingginya semangat petani } \\
\text { untuk melakukan } \\
\text { pengembangan lada }\end{array}$ & 0,129 & 4 & 0,516 \\
\hline 5 & $\begin{array}{l}\text { Lada memiliki aroma dan rasa } \\
\text { yang khas }\end{array}$ & 0,129 & 4 & 0,516 \\
\hline \multicolumn{2}{|c|}{ Jumlah S } & & 20 & 2,597 \\
\hline & Kelemahan (W) & & & \\
\hline 1 & Terbatasnya pengetahuan petani & 0,048 & 1,5 & 0,072 \\
\hline 2 & Kebutuhan air yang terbatas & 0,081 & 2,5 & 0,203 \\
\hline 3 & Minimnya peralatan mesin & 0,081 & 2,5 & 0,203 \\
\hline 4 & $\begin{array}{l}\text { Keterbatasan lahan yang } \\
\text { dimiliki }\end{array}$ & 0,048 & 1,5 & 0,072 \\
\hline 5 & $\begin{array}{l}\text { Permintaan konsumen yang } \\
\text { lebih tinggi daripada jumlah } \\
\text { lada }\end{array}$ & 0,097 & 3 & 0,291 \\
\hline \multicolumn{2}{|c|}{ Jumlah W } & & & $\mathbf{0 , 8 4 1}$ \\
\hline \multicolumn{2}{|c|}{ Total Bobot } & $\mathbf{1 , 0 0}$ & & \\
\hline \multicolumn{2}{|c|}{ Total Skor ( S-W) } & & & 1,756 \\
\hline
\end{tabular}

Sumber: Data Primer (Diolah, 2016)

\section{Faktor Kekuatan (Strengths)}

Kekuatan yang diartikan sebagai suatu bentuk unsur kelebihan yang berasal dari lingkungan internal yang mencakup berbagai aspek yang menguntungkan yang bersumber dari dalam usaha pengembangan lada itu sendiri. Berikut merupakan faktor kekuatan yang dimiliki usaha pengembangan lada di Desa Blang Panyang yaitu:

a. Bibit yang sudah di sertifikasi

Bibit yang digunakan dalam usaha pengembangan lada di Desa Blang Panyang ini sudah disertifikasi sehingga tidak perlu membeli dari luar Aceh. Hal ini merupakan

Strategi Pengembangan Lada (Studi kasus Kelompok Tani Indatu di Desa Blang Panyang Kecamatan 
tindakan yang dapat membantu perekenomian di Aceh sama seperti masa kejayaan lada di Aceh dahulu, sehingga pada faktor kekuatan yang didapatkan dari hasil pengamatan memiliki bobot 0,145 dengan rating sebesar 4,5 dan skor 0,652.

\section{b. Memiliki lahan yang sesuai}

Lahan yang sesuai memudahkan para petani untuk dapat membudidayakan atau mengembangkan usaha tanamannya sehingga dapat mencapai hasil yang diharapkan. Lahan adalah faktor penentu tanaman tersebut bisa tumbuh dengan baik atau tidak. Lokasi lahan di Desa ini tergolong sesuai karena iklim tropis dan suhu udara di atas $24^{\circ} \mathrm{C}$ sehingga pada faktor kekuatan yang didapatkan dari hasil pengamatan memiliki bobot 0,129 dengan rating sebesar 4 dan skor 0,516.

\section{c. Loyalitas petani yang tinggi}

Loyalitas atau kesetiaan petani dalam menjalankan proses pra panen, proses produksi hingga pasca panen sangat mempengaruhi keberlangsungan usaha pengembangan lada ini, sehingga pada faktor kekuatan yang didapatkan dari hasil pengamatan memiliki bobot 0,113 dengan rating sebesar 3,5 dan skor 0,396.

\section{d. Tingginya semangat petani melakukan pengembangan lada}

Semangat Kelompok Tani Indatu merupakan faktor keberhasilan dalam melakukan pengembangan lada. Karena dengan semangat petani tersebut dapat menggerakkan motivasi ke arah yang lebih maju. Disisi lain semangat petani muncul karena tingginya harga lada di pasaran dan sekaligus dapat meningkatkan kesejahteraan petani serta keuntungan hasil yang didapatkan, sehingga pada faktor kekuatan yang didapatkan dari hasil pengamatan memiliki bobot 0,129 dengan rating sebesar 4 dan skor 0,516 .

\section{e. Lada memiliki aroma dan rasa yang khas}

Lada merupakan salah satu rempah yang berbiji kecil, namun meskipun berbentuk sedikit kecil, tanaman rempah ini memiliki rasa dan aroma khas yang kuat. Tanaman rempah ini memiliki permintaan yang tinggi karena kebanyakan orang menyukai rasa dan aroma yang didapatkan dari tanaman rempah ini, sehingga sangat sering digunakan untuk bumbu dapur masakan. Sehingga pada faktor Kekuatan yang didapatkan dari hasil pengamatan memiliki bobot 0,129 dengan rating sebesar 4 dan skor 0,516 .

\section{Faktor Kelemahan (Weakness)}

Kelemahan yang diartikan sebagai suatu bentuk unsur kekurangan yang berasal dari lingkungan internal yang mencakup berbagai aspek yang dapat menjadi kemunduran bagi pada usaha pengembangan lada itu sendiri. Berikut merupakan faktor kekuatan yang dimiliki usaha pengembangan lada di Desa Blang Panyang yaitu:

a. Terbatasnya pengetahuan petani 
Petani di Desa Blang Panyang belum sepenuhnya menguasai wawasan untuk perawatan terhadap tanaman lada disebabkan dikawasan tersebut kurangnya keefektifan pelatihan dari penyuluhan pertanian. Sehingga pada faktor kelemahan yang didapatkan dari hasil pengamatan memiliki bobot 0,048 dengan rating sebesar 1,5 dan skor 0,072 .

\section{b. Kebutuhan air yang terbatas}

Persediaan air yang terbatas ini akan dapat berpengaruh terhadap produksi yang akan datang. Karena persediaan air sangat dibutuhkan bagi tanaman lada dan lainnya. Apalagi lahan yang tersedia cukup luas sehingga persediaan air untuk dialirkan belum maksimal, sehingga pada faktor kelemahan yang didapatkan dari hasil pengamatan memiliki bobot 0,081 dengan rating sebesar 2,5 dan skor 0,203.

\section{c. Minimnya peralatan dan mesin}

Minimnya peralatan untuk sanitasi dan mesin pasca panen yang masih belum memadai mempengaruhi cepat atau lambatnya proses produksi lada yang dilakukan. Sementara pada Kelompok Tani Indatu cenderung masih menggunakan cara tradisional. Sehingga pada faktor kelemahan yang didapatkan dari hasil pengamatan memiliki bobot 0,081 dengan rating sebesar 2,5 dan skor 0,203.

\section{d. Keterbatasan lahan yang dimiliki}

Di Desa Blang Panyang saat ini masih terbatasnya lahan yang dimanfaatkan menjadi lahan pertanian. Lahan yang tersedia kurang lebih 200 hektar dikonversikan menjadi lahan non pertanian dikarenakan lahan tersebut dekat dengan jalan yang mendekati kota dan lahan tidur milik pemerintah yang belum dimanfaatkan. Dengan kondisi yang terjadi, lahan yang tersedia mulai sempit. Pemerintah Kota Lhokseumawe mengusahakan lahan tidur untuk diaktifkan dan dimanfaatkan untuk para Kelompok Tani Indatu dalam pengembangan lada. Sehingga pada faktor kelemahan yang didapatkan dari hasil pengamatan memiliki bobot 0,048 dengan rating sebesar 1,5 dan skor 0,072 .

e. Permintaan konsumen lebih tinggi daripada jumlah lada

Menurut Kelompok Tani Indatu permintaan lada di Kota Lhokseumawe cukup tinggi. Setiap kali panen hasilnya langsung habis terjual di pasar tradisional Lhokseumawe. Tanaman Lada panen 7 bulan sekali. Setiap kali panen bisa mencapai $300 \mathrm{~kg}$ dan langsung habis terjual di pasar Kota Lhokseumawe. Dengan kondisi yang terjadi permintaan konsumen terhadap lada lebih tinggi daripada jumlah lada yang tersedia dikarenakan lahan yang tersedia mulai berkurang. Pada faktor kelemahan ini didapatkan dari hasil pengamatan sehingga memiliki bobot 0,097 dengan rating sebesar 3 dan skor 0,291.

Pada tabel 1 Matrik IFAS yang di atas memperlihatkan bahwa skor terbesar yang menjadi kekuatan usaha adalah bibit yang sudah disertifikasi terhadap usaha pengembangan 
lada di Desa Blang Panyang dengan bobot 0,145 rating sebesar 4,5 dan dengan skor tertinggi adalah 0,652. Faktor ini dianggap sebagai kekuatan utama karena dengan bibit yang sudah disertifikasi dapat mencapai produksi yang optimal. Sedangkan untuk kelemahan dari usaha pengembangan lada di Desa Blang Panyang berada pada permintaan konsumen lebih tinggi daripada jumlah lada memiliki nilai bobot 0,097 dengan rating 3 dan memiliki skor 0,291.

\section{B. Faktor Eksternal Usaha Pengembangan lada}

Faktor eksternal pada usaha pengembangan lada yang menjadi variabel dalam analisis SWOT terdiri dari Peluang (O) dan Ancaman (T) dapat dilihat pada Tabel 2.

Tabel 2. Matrik Strategi Eksternal (External Strategic Factors Analysis Summary)

\begin{tabular}{|c|l|c|c|c|}
\hline \multirow{2}{*}{ No } & \multicolumn{1}{|c|}{ Faktor Eksternal } & \multirow{2}{*}{ Bobot } & \multirow{2}{*}{ Rating } & Skor \\
\cline { 2 - 4 } & Peluang (O) & 0,129 & 4 & 0,516 \\
\hline 2 & Tingginya potensi harga lada di pasar & 0,129 & 4 & 0,516 \\
\hline 2 & Tersedianya pangsa pasar yang luas & 0,129 & 4 & 0,516 \\
\hline 3 & Tersedianya lahan yang masih belum digunakan & 0,129 & 4 & 0,516 \\
\hline 4 & Adanya teknologi budaya yang diperkenalkan & 0,129 & 4 & 0,516 \\
\hline 5 & Terbukanya peluang untuk melakukan diversifikasi produk & 0,145 & 4,5 & 0,652 \\
\hline 6 & Adanya dukungan dari Pemerintah & & & $\mathbf{3 , 2 3 2}$ \\
\hline Jumlah O & & & \\
\hline & Ancaman (T) & 0,064 & 2 & 0,128 \\
\hline 1 & Munculnya pesaing & 0,064 & 2 & 0,128 \\
\hline 2 & Rentannya hama dan penyakit & 0,081 & 2,5 & 0,128 \\
\hline 3 & Biaya sarana produksi yang tinggi & $\mathbf{0 , 9 9 9}$ & 31 & $\mathbf{2 , 4 7 3}$ \\
\hline Jumlah T
\end{tabular}

Sumber : Data Primer (Diolah, 2016)

\section{Faktor Peluang (Opportunities)}

Peluang merupakan bentuk mendukung yang berasal dari lingkungan eksternal, yang mencakup berbagai aspek, sehingga dapat memberi dukungan untuk bertahannya usaha pengembangan lada. Berikut indikator dari variabel peluang $(\mathrm{O})$ terdiri dari :

\section{a. Tingginya potensi harga lada di pasar}

Lada tetap menjadi primadona di dunia perdagangan hasil bumi terutama untuk rempah-rempah. Karena nilai transaksi dagangnya terus mengalami peningkatan dikarenakan berkembangnya usaha makanan, berkembangnya industri farmasi, 
kosmetika yang menggunakan bahan baku lada. Hal ini suatu pertanda bila pangsa pasar terhadap tanaman lada cukup bagus, sehingga pada faktor peluang yang didapatkan dari hasil pengamatan memiliki bobot 0,129 dengan rating sebesar 4 dan skor 0,516 .

\section{b. Tersedianya pangsa pasar yang luas}

Sebagai salah satu daerah produksi lada di Kota Lhokseumawe, masih banyak pangsa pasar yang belum dimasuki oleh Kelompok Tani Indatu. Sejauh ini petani Indatu memasarkan produk mereka sampai ke pasar Inpres Pasar Induk di Kota Lhokseumawe, sehingga masih banyak pasar yang belum dimasuki yang berdampak baik bagi perkembangan usaha ini. Faktor peluang yang didapatkan dari hasil pengamatan memiliki bobot 0,145 dengan rating sebesar 4 dan skor 0,516.

c. Tersedianya lahan yang masih belum digunakan secara optimal

Lahan yang tersedia masih belum banyak dimanfaatkan untuk tanaman pertanian. Masih banyak lahan yang tidur akibat kurangnya pergerakan petani dan pemerintah untuk membangun pertanian lebih maju serta kurangnya kreatifitas dalam menciptakan pertanian yang berbisnis, sehingga pada faktor peluang yang didapatkan dari hasil pengamatan memiliki bobot 0,129 dengan rating sebesar 4 dan skor 0,516.

\section{d. Adanya teknologi budidaya yang diperkenalkan}

Lada perdu dan lada berjalan merupakan teknologi budidaya yang diperkenalkan oleh BPTP Aceh langsung ke Petani di Desa Blang Panyang. Kedua teknologi budidaya ini merupakan inovasi yang dilakukan dengan tujuan dapat mengefesiensikan biaya yang dikeluarkan. Secara pengertian, lada perdu adalah lada yang ditanam tanpa tiang panjatan berupa tiang beton atau pohon kayu inangnya, jadi dibiarkan tumbuh berbentuk semak perdu begitu saja di tanah. Keuntungan dari lada perdu ini adalah mempermudah saat pemanenan karena tidak perlu memakai tangga. Sedangkan pada lada berjalan, teknologi budidaya ini dikembangkan untuk mengatasi keterbatasan lahan dan 'portable' (bisa dipindahkan kapan saja). Caranya adalah menanam lada di dalam pot kemudian diberi 'tajar' (tiang panjat) yang terbuat dari pipa paralon yang dililit dengan ijuk. Sehingga pada Faktor peluang yang didapatkan dari hasil pengamatan memiliki bobot 0,129 dengan rating sebesar 4 dan skor 0,516.

\section{e. Terbukanya peluang untuk melakukan diversifikasi produk}

Diversifikasi adalah usaha memperluas macam produk yang akan dijual dan sebuah strategi usaha pengembangan lada di Desa Blang Panyang untuk menaikkan penetrasi pasar. Ada berbagai alasan yang mendorong suatu usaha mengadakan diversifikasi produk yaitu kemungkinan akan mendapatkan keuntungan akan lebih besar, sehingga pada faktor peluang yang didapatkan dari hasil pengamatan memiliki bobot 0,129 dengan rating sebesar 4 dan skor 0,516.

f. Adanya dukungan dari pemerintah

Strategi Pengembangan Lada (Studi kasus Kelompok Tani Indatu di Desa Blang Panyang Kecamatan 
Pemerintah Kota Lhokseumawe mendukung sepenuhnya untuk membantu pertanian yang lebih maju di Desa Blang Panyang dengan memberikan bantuan bibit dan penyuluhan untuk dapat membantu proses pengembangan lada dan menjadikan komoditi lada sebagai ikon Kota Lhokseumawe sekaligus meningkatkan perekonomian masyarakat petani di Aceh, sehingga pada faktor peluang yang didapatkan dari hasil pengamatan memiliki bobot 0,145 dengan rating sebesar 4,5 dan skor 0,652 .

\section{Faktor Ancaman}

Ancaman merupakan bentuk yang akan mengakibatkan kemunduran bagi usaha pengembangan lada yang berasal dari luar, yang mencakup berbagai aspek, sehingga dapat mengakibatkan kerugian bagi usaha pengembangan lada. Berikut indikator dari variabel ancaman $(\mathrm{T})$ terdiri dari :

\section{a. Munculnya Pesaing baru}

Pesaing merupakan ancaman bagi suatu usaha yang bergerak dibidang produk yang homogen. Persaingan antar usaha jenis yang sama juga membuat pelaku usaha untuk lebih kreatif dalam menjalankan usahanya. Persaingan biasanya terjadi bila banyak usaha yang terus berkembang dalam hal kualitas produk yang dihasilkan, harga serta kenyamanan dalam bagian pelayanan. Untuk itu Kelompok Tani Indatu mengembangkan lada pada strategis yang memaksimalkan kondisi usaha yang terjadi, sehingga pada faktor ancaman yang didapatkan dari hasil pengamatan memiliki bobot 0,064 dengan rating sebesar 2 dan skor 0,128 .

\section{b. Hama dan Penyakit.}

Hama dan penyakit merupakan ancaman yang serius karena pada umumnya menimbulkan dampak yang dapat merusak tanaman lada secara fisik dan fisiologisnya, sehingga dapat mempengaruhi penurunan fungsi pada tanaman tersebut. Tanaman Lada milik Kelompok Tani indatu saat ini diserang oleh hama dan penyakit terutama penggerek batang, penghisap bunga, kepik penghisap buah, penyakit layu, penyakit keriting daun, penyakit jamur pada daun, dan penyakit busuk pangkal batang. Akan tetapi hama dan penyakit tersebut mampu ditangani oleh Kelompok Tani Indatu dengan cara pemangkasan ranting atau cabang yang terserang hama dan melakukan penyemprotan pestisida nabati. Untuk itu pada faktor ancaman yang didapatkan dari hasil pengamatan memiliki bobot 0,064 dengan rating sebesar 2 dan skor 0,128 .

\section{c. Biaya sarana produksi yang tinggi}

Harga pestisida dan pupuk tergolong mahal. Kenaikan harga BBM adalah salah satu yang menyebabkan berbagai sarana produksi menjadi tinggi harganya sarana produksi, sehingga pada faktor ancaman yang didapatkan dari hasil pengamatan memiliki bobot 0,081 dengan rating sebesar 2,5 dan skor 0,203. 
Pada tabel 2 Matrik EFAS yang di atas memperlihatkan bahwa skor terbesar yang menjadi peluang usaha adalah adanya dukungan dari pemerintah terhadap usaha pengembangan lada di Desa Blang Panyang dengan bobot 0,145 rating sebesar 4,5 dan dengan skor tertinggi adalah 0,652. Faktor ini dianggap sebagai peluang utama karena dengan adanya dukungan dari pemerintah dapat memperkuat strategi yang akan dilakukan untuk pengembangan lada sehingga tercapainya kesejahteraan petani. Sedangkan untuk ancaman dari usaha pengembangan lada di Desa Blang Panyang adalah biaya sarana produksi yang tinggi yang mencapai skor tertinggi dengan nilai bobot 0,081 dengan rating 2,5 dan memiliki skor 0,203 .

\section{Strategi Pengembangan Usaha}

\section{a. Pendekatan Kuantitatif Analisis SWOT}

Setelah dilakukannya identifikasi faktor internal dan faktor eksternal melalui matriks IFAS dan matrik EFAS maka diperoleh angka untuk faktor internal yaitu dengan total kekuatan sebesar 2,597 dan total kelemahan sebesar 0,841, sehingga diperoleh angka 1,756 yang menjadi titik pada sumbu X. Faktor eksternal diperoleh angka total peluang sebesar 3,232 dan total ancaman sebesar 0,459 , sehingga diperoleh angka 2,773 yang merupakan titik pada sumbu Y pada diagram SWOT (Pearce, 1997).

1. Faktor Kekuatan usaha pengembangan lada sebesar $\quad=2.597$

2. Faktor Kelemahan usaha pengembangan lada sebesar $\quad=0.841$

3. Faktor Peluang usaha pengembangan lada sebesar $\quad=3.232$

4. Faktor Ancaman usaha pengembangan lada sebesar $\quad=0.459$

Dari skor pembobotan di atas selanjutnya di plotkan pada gambar analisa diagram SWOT. Dari perpotongan keempat garis Faktor Kekuatan, Kelemahan, Peluang dan Ancaman, maka koordinatini melalui perhitungan dibawah ini.

\begin{tabular}{|ccc|}
\hline Skor Kekuatan - Skor Kelemahan : & Skor Peluang-Skor Ancaman \\
$2,59-0,841$ & $:$ & $3,232-0,459$ \\
$\mathbf{1 , 7 5 6}$ (IFAS) & $:$ & $\mathbf{2 , 7 7 3}$ (EFAS) \\
\hline
\end{tabular}

Strategi Pengembangan Lada (Studi kasus Kelompok Tani Indatu di Desa Blang Panyang Kecamatan 


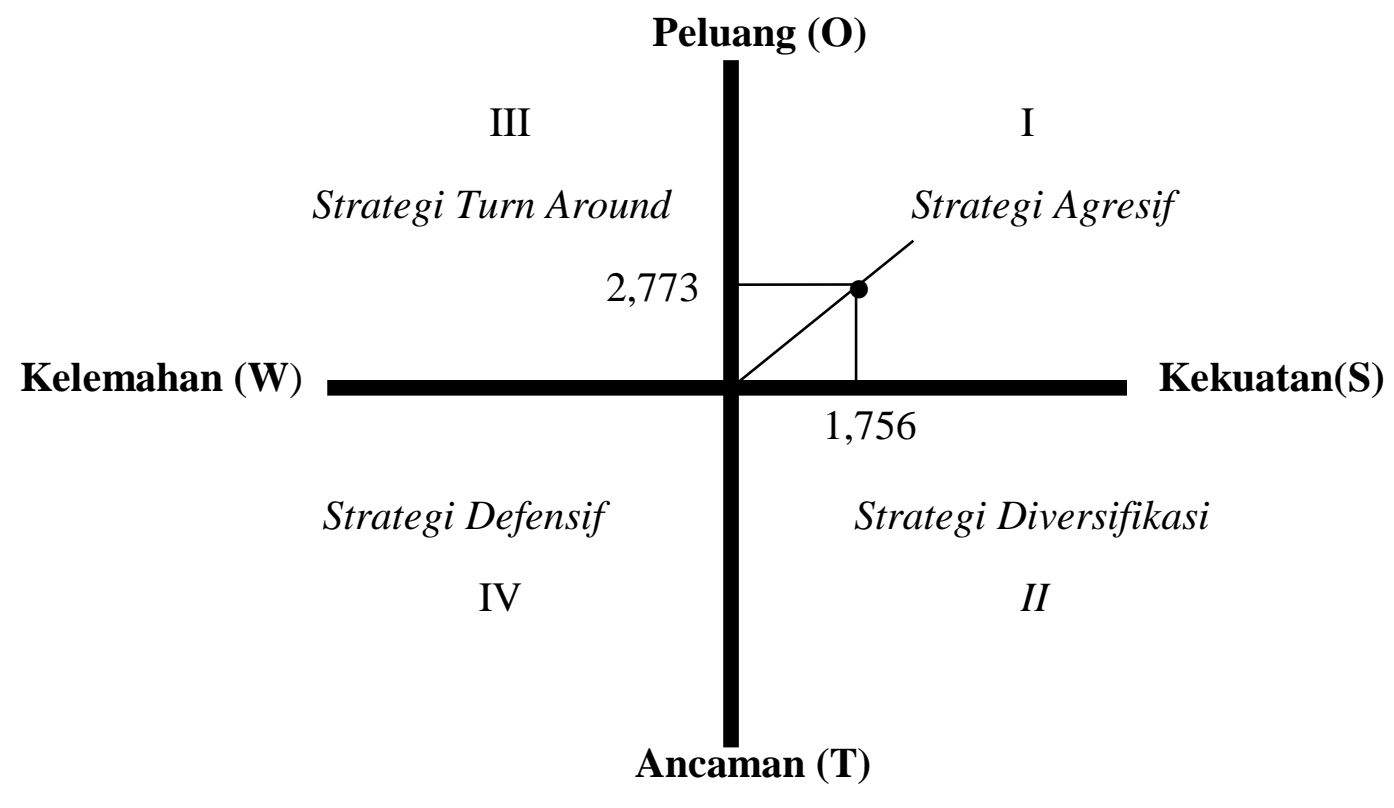

Gambar 1. Posisi Usaha Pengembangan Lada dalam Diagram SWOT (Rangkuti, 2003).

Posisi Usaha Pengembangan Lada di Desa Blang Panyang seperti yang terlihat pada gambar 1 berada pada kuadran 1. Posisi ini sangat menguntungkan suatu usaha, karena usaha tersebut memiliki kekuatan serta mampu memanfaatkan peluang yang tersedia. Strategi yang harus diterapkan dalam kondisi ini adalah strategi agresif, yang artinya usaha tersebut sangat dimungkinkan untuk terus berkembang, meningkatkan pertumbuhan dan meraih kemajuan yang optimal.

\section{b. Pendekatan Kualitatif Analisis SWOT}

Berdasarkan kekuatan, kelemahan, peluang serta ancaman yang diperoleh dari faktor internal dan faktor eksternal, maka dapat di formulasikan alternatif strategi dengan menggunakan matriks SWOT (Kearns, 1992). 
Tabel 3. Alternatif Strategi dengan Matriks SWOT

\begin{tabular}{|c|c|c|}
\hline Internal & $\begin{array}{l}\text { Kekuatan (Strengths) } \\
\text { - Bibityang sudah di sertifikasi } \\
\text { (S1) } \\
\text { - Memiliki lahan yang sesuai (S2) } \\
\text { - Loyalitas petani yang tinggi (S3) } \\
\text { - Tingginya semangat petani (S4) } \\
\text { untuk pengembangan lada (S5) } \\
\text { - Lada memiliki aroma dan rasa } \\
\text { yang khas (S6) }\end{array}$ & $\begin{array}{l}\text { Kelemahan (Weakness) } \\
\text { - Terbatasnya pengetahuan } \\
\text { petani (W1) } \\
\text { - Kebutuhan air yang terbatas } \\
\text { (W2) } \\
\text { - Minimnya peralatan mesin } \\
\text { (W3) } \\
\text { - Keterbatasan lahan yang } \\
\text { dimiliki (W4) } \\
\text { - Permintaan konsumen lebih } \\
\text { tinggi daripada jumlah } \\
\text { produksi lada (W5) }\end{array}$ \\
\hline $\begin{array}{l}\text { Peluang (Opportunities) } \\
\text { - Tingginya potensi harga lada } \\
\text { di pasar (O1) } \\
\text { - Tersedianya pangsa pasar yang } \\
\text { luas (O2) } \\
\text { - Tersedianya lahan yang masih } \\
\text { belum digunakan secara } \\
\text { optimal (O3) } \\
\text { - Adanya teknologi budidaya } \\
\text { yang diperkenalkan (O4) } \\
\text { - Terbukanya peluang untuk } \\
\text { melakukan diversifikasi } \\
\text { produk (O5) } \\
\text { - Adanya dukungan dari } \\
\text { pemerintah (O6) }\end{array}$ & $\begin{array}{l}\text { Strategi S-O } \\
\text { - Tingginya potensi harga lada } \\
\text { dipasar di tentukan dengan bibit } \\
\text { yang sudah di sertifikasi (S1- O1) } \\
\text { - Tingginya semangat petani akan } \\
\text { mampu menggunakan teknologi } \\
\text { budidaya (S4-O4) } \\
\text { - Loyalitas petani yang tinggi akan } \\
\text { mencipatakan dukungan dari } \\
\text { pemerintah (S3-O6) }\end{array}$ & $\begin{array}{l}\text { Strategi W-O } \\
\text { - Pengetahuan petani akan } \\
\text { bertambah luas jika adanya } \\
\text { dukungan dari pemerintah } \\
\text { ( W1-O6) } \\
\text { - Lahan yang digunakan } \\
\text { secara optimal akan } \\
\text { meningkatkan jumlah } \\
\text { produksi lada (W5-O3) }\end{array}$ \\
\hline $\begin{array}{l}\text { Ancaman (Threats) } \\
\text { - Munculnya pesaing usaha } \\
\text { yang sejenis (T1) } \\
\text { - Rentannya hama dan penyakit } \\
\text { (T2) } \\
\text { - Biaya sarana produksi yang } \\
\text { tinggi (T3) }\end{array}$ & \begin{tabular}{l}
\multicolumn{1}{c}{ Strategi S-T } \\
- Dengan penggunaan bibit yang \\
sudah disertifikasi mampu \\
mengahdapi pesaing usaha \\
sejenis (S1-T1) \\
- Memiliki lahan yang sesuai dapat \\
mengendalikan biaya sarana \\
produksi (S2-T3)
\end{tabular} & $\begin{array}{l}\text { Strategi W-T } \\
\text { - Meningkatnya pengetahuan } \\
\text { petani mampu menghadapi } \\
\text { para pesaing (W1-T1) } \\
\text { - Rendahnya serangan hama } \\
\text { dan penyakit meningkatkan } \\
\text { jumlah produksi lada }\end{array}$ \\
\hline
\end{tabular}

Berdasarkan tabel 3 diatas memperlihatkan bahwa dapat dirumuskan beberapa strategi yang bisa digunakan untuk peningkatan serta kemajuan usaha pengembangan lada di Desa Blang Panyang strategi yang dapat diterapkan adalah:

\section{Strategi S-O}

Strategi S-O ini adalah strategi yang menggunakan kekuatan untuk memanfaatkan peluang yang ada. Adapun strateginya adalah sebagai berikut: 
- Tingginya potensi harga lada dipasar di tentukan dengan bibit yang sudah di sertifikasi.

- Tingginya semangat petani akan dapat meningkatkan pengetahuan dalam penggunaan teknologi budidaya.

- Loyalitas petani yang tinggi akan menciptakan dukungan dari pemerintah.

\section{Strategi S-T}

Strategi S-T adalah Strategi yang memanfaatkan kekuatan untuk mengatasi ancaman yang akan terjadi, strategi tersebut antara lain:

- Dengan penggunaan bibit yang sudah disertifikasi mampu mengahdapi pesaing usaha sejenis.

- Memiliki lahan yang sesuai dapat mengendalikan biaya sarana produksi.

Strategi W-O dan W-T juga dapat menjadi alternatif tersendiri bagi usaha pengembangan lada tapi dikarenakan pada kuadran I mendukung strategi agresif, maka alternatif strategi W-O dan W-T hanya akan menjadi cadangan strategi bila sewaktuwaktu terjadi sesuatu yang tidak diharapkan pada usaha pengembangan lada di Desa Blang Panyang.

\section{KESIMPULAN DAN SARAN}

Berdasarkan hasil penelitian yang telah dilakukan, maka dapat diambil kesimpulan bahwa sebagai faktor internal dan eksternal mempengaruhi usaha pengembangan lada di Desa Blang Panyang. Berdasarkan hasil analisis SWOT, strategi pengembangan yang sesuai untuk usaha pengembangan lada di Desa Blang Panyang adalah Strategi Agresif yaitu strategi yang sangat mendukung usaha untuk terus berkembang sehingga pelaku usaha bisa memanfaatkan peluang dan kekuatan yang ada dengan optimal.

Adapun saran yang diberikan dari hasil penelitian ini agar Kelompok Tani Indatu dapat terus berkembang dalam pengetahuan dan wawasan terhadap pencapaian pengembangan lada, diharapkan juga kepada para kelompok petani indatu untuk terus menjaga loyalitas dalam bertani agar dapat menguasai pertanian yang berkelanjutan sehingga mampu bersaing dalam skala nasional maupun internasional dan diharapkan kepada pemerintah daerah agar dapat memberikan dukungan yang maksimal dan bantuan secara intensif dalam pengembangan lada.

\section{DAFTAR PUSTAKA}

Aliyah, R., Gumilar, I,. Maulina, I. 2015. Strategi Pengembangan Usaha Pengolahan Abon Ikan (Studi Kasus Rumah Abon Di Kota Bandung. Unpad. Kota Bandung.

Direktorat Jenderal Bina Produksi Perkebunan, 2002. StatistikPerkebunan Indonesia. Departemen Pertanian. Jakarta. 
Kearns, Kevin P. 1992. From Comparative Advantage to Damage Control: Clarifying Strategic Issues Using SWOT Analysis, Nonprofit Management and Leadership 3.

Kemala, S. 2006. Strategi Pengembangan Sistem Agribisnis Lada untuk Meningkatkan Pendapatan Petani. Balai Penelitian Tanaman Obat dan Aromatik. Bogor.

Nazir, M. 2005. Metode Penelitian. Ghalian Indonesia. Jakarta.

Nurmagribah, M. 2006. Strategi Pengembangan Usaha Studi Kasus pada Diana Bakery. UIN Syarif Hidayatullah. Jakarta.

Pearce, John A. Dan Robinson, Richard B. 1997. Pendekatan Kuantitatif Analisis SWOT. Jakarta: Salemba Empat.

Rangkuti, F. 2003. AnalisisSWOT: Teknik mengukur dan Strategi Meningkatkan Kepuasan Pelanggan. PT Gramedia Pustaka Utama. Jakarta.

Rangkuti, F. 2006. Analisis SWOT: Teknik mengukur dan Strategi Meningkatkan Kepuasan Pelanggan. PT Gramedia Pustaka Utama. Jakarta.

Wahid, P. 1996. Identifikasi Tanaman Lada. Monograf Tanaman Lada. Balittro: hal. 27-32. 